\title{
LOS MOVIMIENTOS TERRORISTAS ANTE EL NUEVO ORDEN MUNDIAL DE LA INFORMACIÓN
}

\author{
Fernando Ripoll Molines \\ Universidad Complutense, Dep. Periodismo, Madrid, España.
}

\section{Resumen:}

El acceso a los medios de comunicación ha permitido conocer y vivir situaciones de violencia, que sin pertenecer necesariamente a nuestro entorno social o geográfico, se han relacionado con reivindicaciones sociales, nacionalistas o religiosas. Sin embargo no es un fenómeno reciente, aunque la inmediatez de dichos medios nos haga pensar lo contrario. Todo esto hace que dicha forma de reivindicación despierte el interés de analistas políticos, sociólogos, psicólogos, etc.; en cuanto que dichos actos son llevados a cabo por grupos humanos que pueden pertenecer a similares ideologías políticas aunque no geográficas, compartir una identificación lingüística o religiosa, representar a minorías étnicas, cuyo objetivo final les lleva a emplear acciones muy violentas como un método más incardinado en un plan que por supuesto tiene en cuenta el impacto que estos tienen.

Todos los grupos terroristas modernos necesitan la publicidad y cuanto más pequeños son, más la precisan. Partiendo de esta idea, es obvio que la elección de los objetivos viene determinada por esta circunstancia. Esta estrategia terrorista sólo funciona en los países en donde existe libertad de información, tratándose, en la mayoría de los casos, de países industrializados y de corte democrático, cuya base es la libertad de expresión y comunicación unidas a la libertad de prensa.

Palabras clave: Terrorismo - Nacionalismos - Ideología - Guerrilla - Violencia

\section{INTRODUCCIÓN}

Sobre el fenómeno terrorista existe una abundante bibliografía e infinidad de documentos elaborados en organismos oficiales, centros de estudio, congresos, etc., con enfoques sociológicos, políticos, jurídicos, militares e históricos principalmente. Las mismas organizaciones que practican el terrorismo también producen una gran cantidad de escritos que están al alcance de cualquiera que se interese por estos temas. En los últimos años, debido a la difusión de los medios de comunicación de los actos terroristas y de todo aquello que se relacione con los grupos terroristas, se publican continuamente artículos sobre este tema. Todo esto ofrece al estudioso de este fenómeno un copioso material cuyo análisis ofrece serias dificultades metodológicas ya que se corre el riego de que la atención se desvíe hacia hechos y situaciones puntuales que nos hagan perder la visión de conjunto que es la única que nos puede dar las claves para una comprensión global del fenómeno.

Sin embargo, el terrorismo no es un fenómeno nuevo en la historia de la humanidad. Ya en el Siglo I d.C. existen referencias de sectas o grupos -los sicarios- que 
utilizaban procedimientos y perseguían objetivos que hoy se siguen utilizando empleando las nuevas tecnologías y en el ámbito de la nueva sociedad. Esto nos hace pensar que es un fenómeno social cuyos orígenes están probablemente en la organización de las sociedades al igual que está la guerra.

Siguiendo a Clausewitz, podríamos decir que si la guerra es la oposición entre dos voluntades que tratan de imponerse la una a la otra por la fuerza, el terrorismo se da cuando la fuerza de una de las voluntades es mucho más débil que la otra e intenta imponerse por medios indirectos. Es la estrategia del débil frente al fuerte como decía Mao Tse Tung y le gustaba repetir al general De Gaulle para justificar su reducida fuerza nuclear comparada con la soviética o americana.

Todo esto hace que muchos autores, al analizar el terrorismo, sean conscientes del riesgo que corren a la hora de sacar conclusiones válidas. Al ser un fenómeno provocado por grupos pequeños, siempre clandestinos, con incidencia en las masas por las acciones armadas que realizan y las reivindicaciones por las que luchan algunas de ellas similares a otros grupos que están en la legalidad- se hace muy difícil por una parte conocer exactamente su etiología de los grupos, la verdadera incidencia social que tienen y predecir su evolución o fijar en el tiempo las acciones que van a realizar.

El primer problema con el que uno se encuentra es definir qué es el terrorismo. Al igual que no hay guerra si no hay enfrentamiento armado, se puede afirmar que no hay terrorismo si no se producen "actos terroristas". Esto nos lleva a analizar la evolución de los grupos que han realizado "actos terroristas" para comprender éste fenómeno.

Para Walter Laqueur, el terrorismo se da por oleadas, puede permanecer larvado durante mucho tiempo y surgir en las sociedades libres o semilibres en cualquier momento. Este mismo autor opina que hoy en día los grupos terroristas no se enorgullecen de contar con detalladas justificaciones ideológicas, aunque, en general,

tengan el mismo substrato de pensamiento y estén manejados por control remoto. Esta idea fundamenta la creencia de que existe una red del terrorismo internacional cuya labor principal sería prestar apoyo a los diferentes grupos existentes (formación de activistas, financiación, suministros de armas y explosivos, etc.) y posibilitar las relaciones entre ellos.

Por otro lado el terrorismo no es una ideología, sino una estrategia para la insurrección que puede usarse por personas con convicciones políticas muy diferentes. Se apoya en la llamada "guerrilla urbana", nombre de origen Tupamaro, que nace ante la imposibilidad de llevar a cabo la guerrilla convencional. Esta idea es importante ya que explica la transición que existe entre dos formas de lucha armada, transición obligada por la cada vez más débil capacidad de acción de unas minorías que no aceptan el modelo sociopolítico en el que viven.

Existen grupos terroristas nacionalistas/separatistas (IRA, ETA) y otros cuyo objetivo es cambiar las estructuras sociales y de poder de una nación o incluso del mundo. (Baader-Meinhof, Brigadas Rojas... etc.) 
Todo ello hace que me haya encontrado con una cantidad enorme de imprecisiones a la hora de acotar el campo de estudio. Si a esto se une el exceso de documentación, los límites de este trabajo, la existencia en Europa de un terrorismo endógeno y otro exógeno, el resurgimiento de los nacionalismos y el hecho de que se perfilen nuevas formas de acción debido a una mayor disponibilidad de armas y explosivos (incluso nucleares) en el mercado negro internacional ocasionado, en gran parte, por el desmembramiento de la extinta U.R.S.S. y a la falta de control de los estados emergentes, hace que oriente el tema del "Terrorismo en Europa" hacia una labor de síntesis, en intentar una aproximación a su definición, cómo nace y en qué se apoya el terrorismo moderno (Década de los 60), grupos terroristas más importantes, nuevas formas de actos terroristas, etc..El mundo se ha hecho pequeño y en Europa puede suceder -de hecho sucede- cualquier acto terrorista, no sólo generado por grupos del mismo Continente, sino pertenecientes a cualquier parte del Mundo, siempre y cuando decidan llevar a cabo un acto terrorista en Madrid, París, Londres o cualquier otro lugar.

El trabajo se fundamenta en acontecimientos históricos y contemporáneos de carácter terrorista ocurridos en Europa, con lo que se ofrece la visión de éste fenómeno tal y como se presenta en nuestros días. Esta visión sicrónica y diacrónica del fenómeno per

mite una mejor comprensión del mismo.

\section{APROXIMACIÓN A UNA DEFINICIÓN}

Por la lectura de documentos sobre el terrorismo, se observa la gran preocupación de los diversos autores por intentar definir el concepto de terrorismo. Todos llegan a unas definiciones que son, de alguna forma, parciales. Quizás el más convencido de la inutilidad de ese esfuerzo sea Laqueur cuando nos dice que cualquier intento de buscar una definición no irá más allá de contemplar una de sus facetas.

Por ello, trataremos de señalar una serie de definiciones y, al mismo tiempo, pondremos de manifiesto las imprecisiones y contradicciones que se encuentran.

-El "Diccionario de la Real Academia de la Lengua" recoge dos acepciones:

-Dominación por el terror.

-Sucesión de actos de violencia ejecutados para infundir terror.

-María Moliner, en su "Diccionario del Uso del Español", lo define como: "uso de la violencia, particularmente la comisión de atentados cómo instrumento político".

-La "Convención de Ginebra para la prevención y represión del terrorismo" del año 1937 trata de definir, más que el terrorismo, el "acto terrorista", entendiendo por tal: "la ejecución de actos criminales dirigidos contra el Estado y cuyo fin o naturaleza es provocar el terror entre personalidades determinadas, grupo de personas o público".

La muerte del Almirante Carrero Blanco fue un acto terrorista -un personaje-, pero con una finalidad política. Según un comunicado de ETA "...constituía la pieza clave (se refiere al Almirante) garantizados de la continuidad y estabilidad franquista". 
-La Constitución Española, en el Art" 13, apartado $3^{\circ}$, al referirse al derecho de los extranjeros, en lo referente a la extradición, dice: "...quedan excluidos de la extradición los delitos políticos, no considerando como tal los actos de terrorismo". Éste texto legal no se refiere al terrorismo y sí a los actos terroristas como acciones que se imputan a personas en concreto y no a las organizaciones a las que puedan pertenecer y al amparo de las cuales actúan.

-En una sentencia de la Audiencia Nacional, en su sección la de lo Penal de Madrid, en febrero de 1980, como consecuencia del suceso conocido como la "Matanza de Atocha", al referirse a los hechos que ya no podían calificarse como delitos de terrorismo, por haber desaparecido esa figura en el Código Penal por Ley 82/1978, pero que sí lo eran cuando se produjeron los hechos, dice que sus autores actuaron con "propósito claro y evidente de realizar vengan zas o represalias de carácter social o político mediante la utilización de armas...". Como se observará, se elude la palabra terrorismo pero se introduce el carácter social o político de unas acciones mediante

la utilización de armas.

-El presidente Calvo Sotelo, en su discurso de investidura, al referirse al terrorismo dice "que se inicia en España en la década de los 70...no es un problema de Estado, sino el gran problema que pone en riesgo la propia realidad del Estado". Esta visión del fenómeno se refiere concretamente al terrorismo de ETA cuya reivindicación principal es la creación del Estado vasco para lo cual es necesario el desmembramiento del Estado de cuyo Gobierno era Presidente el Sr. Calvo Sotelo.

Existen infinidad de manifestaciones y escritos que se podrían citar, todas parciales en tanto en cuanto contemplan un aspecto concreto de la cuestión, algunas aportan datos aparente mente nuevos pero una vez analizados no son más que matizaciones que se hacen con motivo de un hecho o una situación concretos. La C.I.A., en un estudio y análisis del terrorismo político, lo define como "la amenaza o el uso de la violencia con fines políticos cuando esa acción intenta influir en la actitud y comportamiento de un grupo distinto al de sus víctimas inmediatas y cuando sus ramificaciones transcienden de las fronteras nacionales".

En el cuerpo legal español ya hemos puesto de manifiesto una serie de imprecisiones: la Constitución se refiere a actos de terrorismo y se juzgan como actos delictivos comunes en tanto que las penas las imponen los jueces de acuerdo con lo que se dice en el Código Penal. No existe una definición generalmente aceptada del terrorismo. Es un término que se elude porque ello implicaría la existencia de una legislación especial para aplicarla a estos casos. La unidad jurídica que se propugna en las constituciones de los países democráticos y el no reconocimiento de que en una sociedad libre puedan existir delitos políticos, hace que cualquier intento de definición legal, en el momento en el que se introduzca la motivación política sea automáticamente rechazada. Ello no es óbice para que los jueces, tal y como he expuesto, lo manifiesten en sus sentencias. El

origen de estas contradicciones está precisamente en esa negativa, es decir, en no admitir que dentro de un Estado determinados grupos basen su acción política en el empleo de las armas. 
El acto terrorista es también objeto de muchas controversias, tanto en lo que se refiere a su utilidad como a su definición. Para algunos de sus teóricos, es incluso rechazado porque tiene una connotación de "mal indiscriminado" en tanto en cuanto puede afectar

a cualquier persona esté o no implicada en la acción. Dice "Che" Guevara..."el terrorismo, medida bastante eficaz, en general, es indiscriminada en sus consecuencias, pues hace víctimas de sus efectos a gente inocente en muchos casos y cuesta gran número de víctimas valiosas para la revolución". Es obvio que el teórico del "foquismo" es partidario de la guerra de guerrillas convencional; para él, la lucha se mantiene en el campo y no en la ciudad. Los "focos" de lucha son los que deben atraer a todos los que están dispuestos a empuñar las armas para establecer un nuevo orden. En la ciudad es imposible llevar a cabo una acción coordinada y permanente.

Marhigella en su "Manual del guerrillero urbano" dice: "a nadie debe arredrar la acusación de asaltante terrorista...ello debe ser considerado como un título de orgullo que enorgullece a cualquier hombre, pues significa la actitud del revolucionario que lucha a mano armada" Esta postura es totalmente opuesta a la de Guevara. En un territorio como Brasil, en donde la casi totalidad de la población se concentra en grandes núcleos urbanos, dejando inmensos territorios inhabitados, algunos de ellos todavía sin explorar las repercusiones que pueden tener las acciones de una guerrilla convencional pueden ser prácticamente nulas, por esta razón Marhiguella ni igual que lo hicieron los Tupamaros, se ve obligado a actuar en los grandes núcleos urbanos; de ahí, la defensa que hace de los actos terroristas, única forma de acción que puede llevar a cabo.

El acto terrorista puede presentarse bajo cualquier forma: colocación de explosivos, ametrallamientos, tiros en plena calle, chantajes, incendios, etc. Por lo general, persiguen una finalidad puramente psicológica; por ello, su objetivo es siempre concreto La supuesta indiscriminación a la que hace referencia Guevara y de la que son participes múltiples autores, es cierta en cuanto a las víctimas que se puedan ocasionar. Pero si los situamos dentro del marco de la estrategia de acción de una organización, pronto descubriremos que lo que se trata es de crear un clima psicológico en los gobernantes que haga que paulatinamente vayan cediendo a sus pretensiones Walter Laqueur sintetiza estas ideas cuando dice: "Cualquier definición del terrorismo político que vaya más allá de señalar el uso sistemático de asesinatos, lesiones y destrucción o de la amenaza de llevar a cabo tales actos con el fin de lograr unos fines políticos, estará abocado a provocar innumerables controversias...". Ésta referencia de Laqueur es la estimación que más se aproxima a lo que entendemos como terrorismo.

En la exposición anterior, se han puesto de manifiesto algunas de las diferentes formas de ver y entender el terrorismo. Para tener una visión más completa del fenómeno, estimo conveniente hacer una aproximación conceptual al mismo.

\subsection{APROXIMACIÓN CONCEPTUAL}

El término terrorismo aparece en la Revolución Francesa para definir una época y un régimen. En esta ocasión, los guillotinamientos sistemáticos llevados a cabo durante 
el período jacobino para librar a Francia de los "impuros" hicieron que nadie se sintiera libre de caer en manos del "Comité de Salvación Pública" y de terminar en la guillotina. Este terrorismo nada tiene que ver con el que presentamos en este trabajo. Si lo reseño es porque con frecuencia, al hablar de terrorismo, algunos pretenden tratar el llamado "terrorismo de Estado", que de hecho ha existido y puede existir, pero es un fenómeno diferente y el único nexo de unión es el empleo de un mismo vocablo.

Un siglo después, se llamará terroristas a los anarquistas rusos que lucharon contra el gobierno autocrático de los zares de 1878 a 1881, y más tarde, a finales del siglo pasado y principios de éste, a la llamada "propaganda por la acción", impulsada por los soviéticos anarquistas, principalmente en España, Francia, Italia y Estados Unidos. Este terrorismo, salvando las diferencias de la sociedad de entonces y la de nuestros días, es muy parecido al de estos momentos. En España, fueron víctimas de acciones de estos terroristas Cánovas del Castillo, Martínez Campos, Canalejas, Dato... por citar sólo nombres ilustres. Es un terrorismo que estará presente en la vida española entre 1890 y 1936 con períodos de hibernación como fue el de la dictadura de Primo de Rivera. Existe abundante bibliografía sobre algunos de sus personajes o hechos concretos pero está todavía por hacer un estudio sistemático del fenómeno que seguramente resulta ría esclarecedor, para un mejor conocimiento de nuestra historia y

para el análisis completo de un movimiento terrorista.

Después de la la Guerra Mundial, aparece la llamada guerrilla revolucionaria. En 1924, Mao Tse Tung inicia una larga lucha que después de múltiples peripecias alcanzará sus objetivos en 1949. El líder chino escribe, sistematizando este tipo de lucha, su obra más

importante "La Guerra Revolucionaria". Afirma en éste documento, "En una guerra de carácter revolucionario, las operaciones de guerrillas son parte necesaria... Estas operaciones de guerrillas no deben ser consideradas como una forma de guerra independiente. No son sino una forma de guerra total...". Mao, en esencia, lo que pretende es un victoria militar. La guerra de guerrillas es una fase para iniciar la acción para más tarde conseguir un ejército convencional que derrote al enemigo. "Che" Guevara, que se inspira en Mao, en el fondo persigue el mismo fin. Aquí, la acción psicológica tiene más importancia cara a la población para reclutar combatientes que hacia el poder político. Su fin no es llegar a una negociación con el Gobierno sino suplantarle.

Después de la $2^{a}$ G.M., la guerra de guerrillas se extenderá sobre todo con los movimientos de independencia de las colonias.

La lucha en Cuba liderada por Fidel Castro, tras un primer fracaso en 1953, tendrá éxito en 1959 con el derrocamiento de Batista. Tiene idéntico planteamiento que el de Mao en China y será el modelo que después intentará implantar "Che" Guevara en Bolivia en donde no tuvo éxito.

Dentro de la independencia de las colonias, merece especial mención el caso argelino. Aquí, la victoria no se obtiene por un hecho de armas, la actuación de la guerrilla condiciona la evolución de los Tratados de Evians fruto de las 
negociaciones de los representantes de la guerrilla y del Gobierno francés. La evolución de la guerra propiciará la llegada al poder de De Gaulle y la obtención por parte de los argelinos de la plena independencia. El cambio sustancial que se produce en este enfrentamiento es que si bien es imposible pensar que los guerrilleros puedan derrotar al ejército francés, la prolongación de la lucha ocasiona en la opinión pública francesa un cansancio que hace que presione al poder para encontrar una pronta solución al problema. Ho Chi Ming ya decía que las colonias obtendrían su independencia en una mesa de negociaciones y que la lucha armada debía de estar subordinada a las necesidades que impusiera la marcha de estas negociaciones. El modelo argelino es quizás el que más ha influido en el terrorismo contemporáneo, no en la parte que se refiere a la acción propiamente dicha, sino en el planteamiento estratégico de crear climas que propicien negociaciones con los poderes del Estado y a partir de ese momento activar la acción con el fin de lograr los objetivos políticos que persiguen.

Estos tres acontecimientos divulgan unos métodos operacionales revolucionarios que se extenderán en Iberoamérica primero y en Europa Occidental, después. Cuba, al igual que Argelia, será lugar de entrenamiento y reunión de los grupos terroristas.

Al transplantar estos procedimientos a las democracias occidentales, nace una forma peculiar de acción revolucionaria que, por su similitud con las acciones anarquistas se denomina terrorismo. En un Estado europeo, no puede existir una guerrilla pero sise pueden llevar a cabo acciones similares a las que a principio de siglo realizaban los anarquistas. Estos no quisieron nunca negociar con el poder, los movimientos contemporáneos tienen como única meta el provocar esas negociaciones.

Dentro del terrorismo contemporáneo español, sobresale ETA. Si analizamos ésta organización, podemos ver las connotaciones que tiene actualmente el término terrorismo.

Nace ETA el 31 de julio de 1959, fundada por Julen Madariaga, Benito Valle, José Manuel Aguirre, Sabino Uribe y Javier Barreño, escindidos del grupo E.K.I.N., creado en 1952 en la Universidad de Deusto e integrado en la disciplina del P.N.V.

Esta organización busca una identidad ideológica que arrope un sentido nacionalista confuso e indefinido. En 1962 tiene lugar la I Asamblea y a partir de este momento, "las elaboraciones ideológicas van a centrarse de forma exclusiva en la búsqueda de un modelo revolucionario válido para los fines y objetivos perseguidos". Como se observará, la finalidad estaba ya predeterminada: una nación sólo encuentra su propia identidad cuando se convierte en Estado. La ideología se convertía en un traje que permitiría asistir a la ceremonia de proclamación del Estado.

Esta búsqueda de un modelo revolucionario válido produce toda una serie de contradicciones, que tendrán como consecuencia una continua fragmentación de la organización. En la I Asamblea, ETA se define como "movimiento vasco revolucionario de liberación nacional, creado en la resistencia patriótica e independiente de todo otro partido, organización u organismo". En un documento posterior, ETA señala que "Habrá que crear y reconocer su legalidad por la fuerza de 
las armas, con plástico y metralletas, precedidos y acompañados por toneladas de propaganda".

Lo anterior define los tres conceptos sobre los que se va a guiar toda la posterior evolución de la organización: la liberación nacional, la revolución y la lucha armada. También nos muestra la línea que va a seguir su evolución. Como se puede ver, se pasa de ese nacionalismo indefinido a la lucha armada y la propaganda como argumentos de legitimidad.

En esas fechas, el concepto de Liberación Nacional está de moda. Las guerras de independencia de las colonias han sido llevadas por grupos que se autodenominan "Frente de Liberación Nacional". El sentimiento nacionalista que origina ETA encuentra en esos frentes de liberación un cobijo cómodo: la liberación de la Nación es un marco de referencia suficiente para no entrar en más detalles.

Tiene la ventaja de proporcionar modelos de lucha que han resultado victoriosos: Mao Tse Tung en China, Fidel Castro en Cuba, Ho Chi Ming parcialmente en Vietnam y el FLN en Argelia. Todos ellos utilizando la guerra de guerrillas tuvieron éxito, bien mediante una victoria militar o imponiéndose en la mesa de negociaciones.

La idea de lucha armada tiene que encontrar una vía que la haga posible. No la encuentran en principio porque la tesis del modelo (Mao o "Che" Guevara) sólo se puede llevar a cabo en territorios no controlados por el Gobierno de la Nación. Este hecho en España es imposible. La organización del territorio español y la fuerza de la que dispone el Gobierno le permiten imponer su autoridad en la totalidad del territorio. La única alternativa era la acción terrorista llevada desde la clandestinidad y la puesta en marcha de un fuerte dispositivo de propaganda. La acción sin la propaganda no tiene sentido. El acto terrorista debe de mostrarse como un hecho diferente del delito común. Por esta razón, los escenarios de la acción deben de ser lugares en donde sea imposible la confusión con un delito común o el silencio de los medios de comunicación social. Estos dos hechos marcan toda la planificación de los actos terroristas que va a llevar a cabo ETA.

El concepto revolucionario es vago y confuso. De alguna manera el concepto del F.L.N., entendido como unión de fuerzas para conseguir la independencia nacional, es el que más se aproxima a su realidad ideológica. Si en un determinado momento ETA es marxista, pienso que es circunstancial y se debe más a la influencia de sus instructores -argelinos, soviéticos, cubanos y libios- que a un planteamiento reflexivo del modelo social deseado.

En la V Asamblea, ETA elabora su modelo de lucha armada. Se apoya en la teoría de los cuatro frentes de Federico Krutving, el político, el económico, el militar y el cultural, que dota a la organización de una estructura capaz de actuar de forma coordinada, aun

que siempre prevalecerá uno de ellos, el militar. Como se puede comprobar, no es más que una síntesis de los modelos analizados con anterioridad y recogidos por este militante de ETA. 
Se apoyan también en la estrategia denominada "acción-represión". Éste ejemplo, tomado de sus propios escritos, es válido para explicar su funcionamiento: "Solicitar ikastola legal, prohibición administrativa, ikastola clandestina, prohibición de la policía y represión particularizada; acción dura, represión militar (metralletas e interrogatorios); acción de todo el pueblo (manifestaciones); represión a todos los niveles (contra todo el pueblo indiscriminadamente). Consecuencia: pueblo unido en pie de guerra". Este planteamiento, aparentemente ingenuo, sólo es posible si se cuenta con un gran apoyo de la sociedad y si la organización tiene la suficiente sensibilidad para ponerse al frente de todas la reivindicaciones sociales existentes sin tener en cuenta si forman parte o no de su programa político. El ejemplo histórico más notorio me el programa de acción que llevó ETA con la central nuclear de Lemóniz. Este ejemplo sobre la "acción-represión" conduce a lo que se llama "acto terrorista", que tiene por finalidad última provocar reacciones de las masas que favorezcan la causa revolucionaria.

En su VI asamblea de enero de 1975, ETA mantiene que básicamente la estrategia de ETA está fundamentada en la aplicación de los principios generales de la guerra revolucionaria". Esta confesión pone en evidencia cuales son los principios en los que se inspiran. Pretender ver el terrorismo como un fenómeno contemporáneo carente de unas normas de actuación y de unos esquemas de acción estudiados y llevados en la práctica en muchas ocasiones con resulta dos muchas veces positivos, es una manera de cederles la iniciativa a ellos y renunciar a establecer líneas de acción que pueden contener e incluso hacer desaparecer las organizaciones que lo practican.

El caso de ETA puede compararse con otras organizaciones que practican el terrorismo en nuestros días y puede ser un modelo de estudio que permite hacer generalizaciones. La diferencia esencial entre los diferentes movimientos de esta naturaleza reside en el apoyo social con el que cuentan. Grupos como el GRAPO el FRAP españoles, la Banda Baader-Meinhof alemana o las Brigadas Rojas italianas se diferencia de ETA o del IRA en el apoyo social que tienen. Los que carecen de apoyo tienen escasa incidencia en la sociedad y por o general después de algunas acciones más o menos espectaculares desaparecen bien por la acción de la policía, bien por la dispersión de los miembros y por lo general por ambas cosas a la vez. El en el otro caso, el problema se enquista en la sociedad y sus acciones pueden perdurar durante un largo período de tiempo.

Por todo lo anterior, cuando decimos que ETA es un grupo terrorista, y calificamos de actos terroristas las acciones llevadas a cabo por ETA, nos estamos refiriendo a una organización clandestina, con unos objetivos políticos concretos y con una estrategia desarrollada con arreglo a unos planes preconcebidos.

\subsection{EL ACTO TERRORISTA}

En la actualidad, es de uso común, que tanto la prensa como los políticos en general, se refieran siempre a una serie de actos cometidos por grupos organizados cuyos fines, puestos de manifiesto por quienes los realizan, son siempre de carácter político. 
Las situaciones de terrorismo en la época actual, tienen un origen primario en grupos organizados que realizan una serie de actos que pueden ser tipificados jurídicamente como delitos comunes. No son actos terroristas aquellos que pueda realizar una persona aisladamente aunque su finalidad sea política. Es importante esta matización para delimitar el fenómeno. La acción individual de un francotirador contra un líder político por su propia iniciativa está fuera de este estudio.

La práctica de éstos delitos busca justificación en la llamada "lucha armada". No se legítima el delito visto de una forma aislada, la legitimización está en el ideal que se quiere alcanzar con esa lucha. Cuando a principios de este siglo unos anarquistas franceses colocaban una bomba en el café Terminus de París causando muchas víctimas, un intelectual de la época escribía: "No importa la sangre si el gesto es bello". Erich Bölh, premio Nobel de literatura, justifica las acciones de la Banda Baader-Meinhof por la grandeza del pensamiento de la periodista Ulrike Meinhof. En España sucede algo parecido con las acciones que realiza ETA. Siempre se ha empleado el mismo argumento: no se trata de juzgar un hecho aislado sino de saber las razones por las que un determinado grupo se ve obligado a realizar acciones de esta naturaleza. Como se verá en esto nada ha cambiado desde que existe el terrorismo.

El grupo, cuando decide emplear la "lucha armada" adopta una estrategia de acción, en función de la capacidad de sus dirigentes, de sus medios humanos y materiales y de los apoyos que reciba. Los actos que realicen, no pueden analizarse aisladamente sino dentro del contexto de "lucha armada". Muchos pueden parecer inconexos y aparentemente no tener ningún nexo de unión. Para la organización están todos incluidos en su programa de acción. Todos tienen su explotación psicológica, unos destinatarios concretos y cualquiera de ellos sirve para dar fe de que la organización sigue estando presente.

Carlos Marighella han sido uno de los grandes teóricos del acto terrorista con sus escritos sobre la "lucha guerrillera urbana" principalmente en su folleto "El minimanual del guerrillero urbano". Tipifica 13 modalidades: Asaltos, emboscadas, tácticas callejeras, huelgas, secuestros, bandas, etc. Algunas de estas acciones, como la huelga, podrían presentar forma legal. Aunque ese texto estaba escrito para Iberoamérica, la realidad es que cualquier grupo que alcance un grado medio de organización, como ETA o IRA, han cubierto la lista en repetidas veces.

En un documento de ETA se dice, "Desde un punto de vista militar, la práctica armada que hemos llevado ha sido a base de acciones aisladas de comandos, dentro de unas perspectivas generales de hostigamiento siguiendo en esto los esquemas clásicos de la guerra de guerrillas bajo forma de activismo". Este texto está tomado casi textualmente de Marighella lo que pone una vez más de manifiesto la influencia de estos teóricos en las organizaciones terroristas.

El acto terrorista en toda su complejidad puede ir desde la legalidad a la ilegalidad, desde el ejercicio de una libertad reconocida por las leyes hasta el delito contemplado en los códigos penales. Limitar su estudio sólo a aquellos hechos que lleven consigo el empleo de armas o explosivos es dejar fuera a una gran parte de las actividades de estos grupos. 
Las técnicas para ejecutarlos están hoy al alcance de todo el mundo interesado en ello. Sin grandes dificultades se puede conseguir documentación adecuada. Como ejemplo, en el año 1977 se vendía libremente en librerías de Nueva York un documento "Terrorist Handbook" en la que se desarrollaban todo tipo de técnicas. Libro que escandalizó y que $A B C$ reseñó. En España, tal como se reseña en la bibliografía que va al final de este trabajo, se pueden adquirir desde hace muchos años y consultar en bibliotecas públicas los libros que explican todas estas teorías.

El acto terrorista, entendido éste tal como lo interpretan los jueces ateniéndose a las leyes vigentes, es un delito común que no define una situación de terrorismo. Se excluyen una serie de hechos que enmarcan una situación social que hace posible que el fenómeno se desarrolle tal y como hemos apuntado con anterioridad.

Los actos terroristas quieren tener una proyección hacia la sociedad. Los delitos comunes, si quedan impunes y sin publicidad, mejor para los autores. Un rasgo definitorio del acto terrorista es el de la autoría: se lo atribuye la organización, nunca uno de sus miembros. Puede que en alguna ocasión no sean reivindicados porque estimen que no sea conveniente para sus fines, pero por lo general la reivindicación es consustancial con cualquiera de estos hechos. Obrando así, la fuerza sólo la tiene la organización y sus miembros son perfectamente sustituibles.

El terrorista tiene un ideal revolucionario. Desea cambiar las estructuras de forma violenta. El acto que realiza puede tener un fin en sí mismo, visto de forma aislada, pero hay que encuadrarlo en el seno de la sociedad y dentro de las actividades que realice en la organización.

El acto terrorista es eminentemente urbano. Así como la guerrilla es básicamente rural, el terrorismo actúa preferentemente en grandes ciudades: Madrid, París, Roma, Milán. Para actuar en medios urbanos más pequeños necesita un apoyo mayor entre la población, como puede ser el IRA en Irlanda o ETA en el País Vasco. Esto lleva consigo la posibilidad de permanecer épocas largas en silencio. El terrorista no domina ningún espacio geográfico.

En la lucha de guerrillas convencional, el enemigo son las Fuerzas Armadas, el terrorismo tiene como enemigo el orden constituido y sus enemigos no son sólo las Fuerzas Armadas, sino cual quiera que colabore o participe de ese poder. Esto le da un carácter más difuso a su acción y amplia su campo de actuación con lo que el efecto sorpresa se verá incrementado. Sus acciones son siempre instantáneas, tiene escasos segundos de duración cuando se trata de hechos de armas. No existirá combate como tal enfrentamiento armado, si este se produce se estimará que algo ha fracasa do en su plan.

En España y también en otros países, siempre se esperan actos terroristas con ocasión de efemérides de acciones producidas pro o contra de ETA, o cuando se organizan conferencias internacionales, negociaciones en relación con el terrorismo, aprovechando las noticias de tales acontecimientos para obtener una mayor publicidad. Sin embargo, las alarmas no siempre se traducen en realidades. La duda que se plantea a la hora de sacar una conclusión es si los dispositivos de seguridad 
han sido eficaces o simplemente que la organización ha decidido no actuar. Es obvio que estas situaciones de alarma favorecen la acción psicológica del terrorismo y obligan al despliegue de grandes dispositivos de seguridad con los costes que esto supone y los inconvenientes que puede producir en la población.

En ésta aproximación a intentar definir lo que es terrorismo nos obliga a proponer la siguiente definición: "Terrorismo es una estrategia revolucionaria llevada a cabo por grupos organizados en la clandestinidad, consistente en la comisión de actos legales e ilegales siendo características esenciales la utilización de la lucha armada, la reivindicación por parte de la organización, el anonimato de los militantes activos, su carácter prioritariamente urbano, la fugacidad de sus acciones violentas, la renuncia a ocupar un territorio y el carácter propagandístico de toda su acción para lograr las metas revolucionarias propuestas"

\section{CARACTERES DEL TERRORISMO MODERNO}

Algunas de las características ya han sido expuestas al desarrollar los apartados anteriores. En la labor de síntesis impuesta por los límites del trabajo aportaré algunas ideas de los teóricos, fundamentalmente de Laqueur en su libro "Terrorismo".

Observa Laqueur que "el terrorismo no se ha dado nunca en los modernos regímenes totalitarios; se han producido intentos de asesinato, pero los medios de control y de represión a disposición del Estado totalitario excluyen la posibilidad del terrorismo organizado". Esta afirmación es discutible por el hecho del férreo control informativo que se lleva a cabo en estos estados. Lo que se puede afirmar es que, si han existido sus acciones, éstas no se han visto reflejadas en los medios de comunicación social por lo cual los públicos no han tenido conocimiento de ellas y su carácter propagandístico se ha visto fuertemente disminuido. Del grupo islámico argelino que actúa en nuestros días, sólo se tiene conocimiento de las acciones que lleva a cabo contra extranjeros. Ni la prensa argelina ni la de otros países reflejan la serie de hechos que se lleva a cabo en el interior del país y que probablemente se producen.

El resurgimiento de los nacionalismos, el derrumbamiento de la U.R.S.S., las condiciones de vida de los nuevos países, la pobreza del tercer mundo, es muy posible que provoquen el nacimiento de nuevos grupos terroristas en el futuro, que gocen de un gran apoyo de la población, por el deseo de vivir en mejores condiciones. Es significativo el crecimiento de organizaciones que usan el terrorismo en el Norte de África. La incapacidad demostrada por los dirigentes políticos de aumentar el nivel de vida de la población, el rápido crecimiento demográfico, el reconocimiento del fracaso político de partidos de carácter socialista, ha llevado a las sociedades, por un lado, a buscar en la emigración una forma de mejorar su nivel de vida y. por otra, a refugiarse en la religión -en el Corán- como solución a sus males. De ahí el nacimiento del fundamentalismo árabe y de grupos terroristas (FISFrente Islámico de Salvación, GIA-Grupo Islámico Armado-etc...). 
Estos hechos tienen que ser motivo de preocupación para los gobiernos europeos: utilizando un término coloquial, se puede introducir una "Quinta Columna" en Europa a través de la emigración.

Por otro lado, el fracaso del Socialismo Soviético, extendido a toda la antigua U.R.S.S. y Países Satélites, en contraste con la economía de los países llamados capitalistas, después de tantos años de sometimiento, ahora se encuentra con grandes dificultades para alcanzar los niveles del resto de países europeos. Eso puede hacer renacer el ansia por los "viejos tiempos" y hacer surgir grupos revolucionarios, con acciones terroristas, que pretendan suprimir el sistema político actualmente establecido. Grupos que extenderían sus acciones por todo el territorio europeo.

Los grupos terroristas, en contraste con las unidades de guerrilleros, no crecen más allá de ciertos límites. Algunas organizaciones, IRA y los terroristas árabes palestinos, por ejemplo, han contado con muchos miembros, pero sólo un grupo pequeño estaba preparado para la acción. Esta limitación viene impuesta por la dificultad de mantener

en la clandestinidad un número elevado de personas. Si habláramos en términos económicos el mantenimiento de un guerrillero urbano es 20 o 30 veces superior al de un guerrillero rural. Por otra parte, el control que se puede ejercer sobre estos activistas es muy militado por lo que la selección de los mismos es muy importante no sólo por lo que se refiere a la acción sino también para la seguridad de la propia organización.

\section{LA INTERNACIONALIZACIÓN DEL TERRORISMO}

Está probado que grupos terroristas de ideologías diferentes han recibido apoyos de varios países. La U.R.S.S. en su guerra fría con Occidente, no dudó en apoyar a grupos para desestabilizar a naciones occidentales o que estaban bajo la órbita de Occidente. Las conexiones son difíciles de probar pero las evidencias son tantas que, a pesar de la negativa sistemática de los dirigentes soviéticos, hoy nadie duda de su existencia.

El terrorismo internacional alcanza su apogeo en los años 70 al producirse una íntima colaboración entre pequeños grupos terroristas de muchos países que actúan con el apoyo de los gobiernos libio, argelino, sirio, norcoreano y cubano principalmente. El apoyo se concreta en la financiación, suministro de armas y explosivos, formación y entrenamiento en campos situados en sus territorios, refugio de sus activistas, etc.. Si bien el terrorismo está condenado por todas los organismos internacionales, la postura de los países mencionados de apoyar a todos los movimientos de liberación hace que

el calificativo de terrorista no lo apliquen a aquellos grupos con los que guardan algún tipo de relación. El problema también se presenta en Occidente. Es necesario recordar que Francia, hasta hace muy poco tiempo, concedía el estatuto de refugiado político a los terroristas de ETA que estaban reclamados por la justicia española.

Cuando se considera la actividad política del grupo que practica el terrorismo como "justa", los actos terroristas que pueda realizar pasan a un segundo término y 
entonces, a los miembros de la organización se les ampara con arreglo a las normas sobre refugiados establecidas por la ONU. Este es uno de los escollos principales para que en esta materia se puedan alcanzar acuerdos internacionales que sean realmente eficaces. Ya se sabe que cuando sobre un determina do punto las posturas están encontradas, la forma de alcanzar un acuerdo es buscar un texto lo suficientemente ambiguo para que cada una de las partes vea sus planteamientos, si no aceptados, sí por lo menos respetados. Esto es el origen de las imprecisiones a las que ya nos hemos referido.

\section{LA PUBLICIDAD DEL ACTO TERRORISTA}

Son muchos los que opinan que lo cuenta no es la magnitud de la operación terrorista, sino la publicidad que pueda alcanzar. Se ha llegado incluso a decir que un acto terrorista es una representación teatral que se realiza para que los medios de comunicación la puedan contar a sus lectores. Todos los grupos terroristas modernos necesitan la publicidad y cuanto más pequeños son, más la necesitan. Con este planteamiento es obvio que la elección de sus objetivos vendrá determinada por esta circunstancia. Ésta estrategia terrorista sólo funciona en los países en donde existe libertad de información. La forma de dar la noticia del acto terrorista es también un tema polémico, pues no sólo el darla, que es un derecho a la información, puede afectar a esa publicidad, sino el contenido de la noticia, el tratamiento que cada medio dé de la misma puede, incluso, con sus medias verdades llegar a crear un clima que favorezca la tesis del terrorismo.

Es en sus primeras acciones armadas, con escasa infraestructura y pocos recursos, cuando los grupos terroristas son más vulnerables ya que no gozarán de apoyo popular. La responsabilidad de los medios de comunicación, entonces, es muy grande.

\section{EL TERRORISMO HOY}

La ola de terrorismo en las zonas urbanas que hoy padecemos empezó a finales de los años sesenta. Se puede dividir en tres grupos:

- Terrorismo separatista (IRA - AI Fatah - ETA).

- Terrorismo iberoamericano (Guerrilla urbana).

- Terrorismo que procede dé fracaso de la Nueva Izquierda; en Alemania Occidental, Italia, América del Norte, Japón.

Se podrían hacer otras clasificaciones ateniéndose a la ideología que los inspira, a los objetivos políticos que persiguen, a las zonas en donde actúan o a cualquier otra circunstancia. Las clasificaciones a fin de cuentas no son más que artificios metodológicos cuya finalidad principal es facilitar el conocimiento global del fenómeno.

\subsection{TERRORISMO NACIONALISTA/SEPARATISTA}

Entendemos éste tipo de terrorismo como el del IRA, AI Fatah, ETA, F.L.Q (Quebec). Los dos primeros han recibido más atención de los medios de comunicación social 
debido al gran impacto de la religión, la palabrería revolucionaria y a sus conexiones internacionales.

El carácter específico del terrorismo del Ulster, tiene sus raíces por una parte en la mística nacional de la lucha antibritánica y por otra, en el miedo de los protestantes. Hoy asistimos a un alto el fuego unilateral (Por parte del IRA) que está lleno de riesgos, pero que abre una puerta a la esperanza.

El terrorismo sistemático del IRA (Ejército Republicano Irlandés) empezó en 1970. El contraterror protestante, U.D.A. y U.F.V también se inició ese mismo año. En realidad lo que sucede en el Ulster es una guerra civil en la que el ejército británico impone ciertas limitaciones interviniendo más como fuerza de pacificación que como combatientes frente a los grupos armados.

La composición social del IRA está formada por la clase trabajadora y la media-baja. El apoyo popular lo reciben por el carácter confesional de cada uno de los grupos. Se establecieron "zonas prohibidas" para los protestantes, y al igual, para los católicos. Las acciones terroristas eran indiscriminadas (bares, tiendas, pubs, transportes públicos...).

Aunque el gobierno irlandés no tenía gran entusiasmo por el IRA, los terroristas podían cruzar Irlanda sin grandes complicaciones, ya que el mismo gobierno no tenía tampoco grandes afectos al gobierno Británico. Las acciones del IRA en territorio irlandés eran muy reducidas, preferentemente sobre prohombres ingleses o norirlandeses. En cualquier caso, la bomba era el medio más usado, utilizándola incluso en Inglaterra.

Conviene analizar el grupo palestino Al Fatah, pues aunque actualmente esté aletargado, de sus acciones otros grupos pueden aprender y pueden resurgir las mismas formas de acción.

Con la creación del estado de Israel, se crea un grupo de resistencia palestino, al no reconocer estos la existencia de un estado judío. Se constituye, en 1964, la O.L.P. (Organización para la Liberación de Palestina), que actuó como una organización de cobertura para Fatah y otros grupos terroristas más pequeños. Una de sus características más importantes es que sus bases están mera de Israel, lo que hace que sus acciones en territorio judío entrañen una mayor dificultad ya que sus activistas residen normalmente fuera del territorio y cuando quieren realizar una acción tienen que penetrar en un territorio en el que no tienen apoyos eficaces.

El intento de poner en marcha un movimiento guerrillero rural en Israel, poco después de la guerra de los Seis Días, fracasó porque el terreno no se prestaba a ello y principalmente porque las tuerzas de seguridad israelí son capaces de controlar la totalidad del territorio, no existiendo zonas de vacío de poder.

La guerrilla palestina ha utilizado principalmente tres tácticas:

- Bombardeo de las colonias desde el otro lado de la frontera.

- Ataques relámpago por los comandos contra colonias o transportes israelíes.

- Ataques contra personas o bienes y secuestros en naciones de terceros países (enorme publicidad). 
Tenía un gran apoyo político y financiero del mundo árabe y de una gran parte de la izquierda de los países occidentales cuando no estaba en el poder. Este es un hecho muy curioso y que merece la pena poner de relieve. En los países libres del mundo occidental el comportamiento de los grupos políticos es diferente según las responsabilidades de poder que tengan. Esto es origen de muchas contusiones. La O.L.P ha encontrado apoyos en lo que podríamos denominar la oposición extraparlamentaria europea. Este mismo sector rué el que apoyo también a otros movimientos terroristas.

Las dificultades enormes de actuar en Israel y las duras represalias de los iraelíes sobre los campos de refugiados de palestinos donde la O.L.P establecía sus bases, hicieron que se desarrollaran nuevas técnicas de actuación encaminadas principalmente a influir en la opinión pública internacional. La firmeza del Gobierno israelí y la hostilidad de la población judía hacia la causa palestina hicieron ver claramente que sólo la presión de la opinión pública internacional podría obligar al gobierno judío a ceder a las pretensiones palestinas. Las nuevas técnicas a las que hacemos referencia son las siguientes:

-Alistar extranjeros en sus filas (la matanza del aeropuerto de Lod en mayo de 1972 fue ejecutada por miembros del Ejército Rojo Japonés).

-Creación de organizaciones "ad hoc" para llevar a cabo operaciones especialmente desagradables 0 que entrañaban complicaciones internacionales (Septiembre Negro) y que aparecían y desaparecían (Águilas de la Revolución Palestina) en la medida que las acciones a realizar lo requerían.

Esto tenía una ventaja; se continuaba la lucha terrorista mientras que la dirección política se disociaba de tales operaciones con lo que no asumía ninguna responsabilidad sobre las acciones que pudieran llevar a cabo. Estos grupos fantasmas se identificaban con la causa que defendía Al Fathah pero se declaraban independientes del mismo.

\subsection{TERRORISMO DE LA NUEVA IZQUIERDA.}

A caballo entre la década de los sesenta y de los setenta surgió y murió un movimiento que inspiró un brote de terrorismo en el mundo occidental -La Nueva Izquierda- que se convirtió en la fuerza principal en las universidades (duró 4 ó 5 años). Son los llamados

hijos del "Mayo del 68" cuyo elemento de unión principal era un profundo sentimiento antiamericano motivado por la intervención americana en Vietnam.

La Nueva Izquierda tenía una ascendencia muy diversa; por un lado se apoyaba en un idealismo, antimilitarismo, indignación ante las desigualdades sociales, ante la pobreza, el hambre y la explotación en el Tercer Mundo. Pero también contaba el aburrimiento, la agresividad y el extremismo desarraigado de toda una generación.

Las ideas que defendían no tenían que ver con el terrorismo, sin embargo con su declive optaron por él..

Así nacen casi simultáneamente varios grupos en diferentes países occidentales. En Japón, surge del Zengakuren la organización extremista estudiantil el Ejército Rojo Unido. Algunos estudiantes alemanes de la extrema izquierda fundaron el Rote 
Armee Frakation (Baader-Meinhof). En España, surgieron el Grapo y el FRAP. Grupos más pequeños aparecieron en Italia (Brigadas Rojas) y en Inglaterra (Angry Brigade). Según Laqueur, "pocas veces en la historia se ha hablado tanto sobre tan pocas personas y tan escasas ideas".

La Banda Baader estaba formada exclusivamente por estudiantes de clase media. Su sistema no era luchar por los oprimidos y explotados en su país, sino destruir las "islas de riqueza", como agentes del Tercer Mundo. Su idea de "guerrilla de las ciudades" era de origen iberoamericano.

Estos grupos desaparecieron o fueron absorbidos por el terrorismo internacional. Sus únicas victorias las obtuvieron en el área de la publicidad, principalmente por el apoyo que recibieron de intelectuales como Jean Paúl Sartre, Jean Genet, Herich Bölh o Marcuse. Estos originaron un debate cuyos ecos se extienden hasta nuestros días.

\subsection{TERRORISMO INTERNACIONAL}

Algunos aspectos del terrorismo internacional ya fueron expuestos al desarrollar los puntos anteriores. Alcanza, a partir de 1970, un gran desarrollo, especialmente en el campo de los secuestros aéreos. Al verse todos los estados afectados por la ola de secuestros pronto se llegó a un acuerdo para poder dar una réplica eficaz que pudiera restablecer la seguridad en el tráfico aéreo. Para ello, fue necesario que todos los países reconociesen que un secuestro aéreo, fueran cuales fueran las causas que lo motivasen, era siempre un delito y los secuestradores serían sometidos a juicio. Esto no se ha cumplido al pie de la letra, pero sí todos los estados se han mostrado reacios a admitir en sus aeropuertos aviones secuestrados y si lo han hecho ha sido como resultado de las negociaciones de los secuestradores con las partes afectadas. Esto nos dice que en cuestiones relativas al terrorismo, a nivel internacional, ante la imposibilidad de llegar a un acuerdo global, se pueden suscribir acuerdos sobre hechos concretos, que sin bien no representan una solución definitiva, ponen límites a las acciones de los grupos terroristas. Este tipo de terrorismo últimamente es menos activo, pero los explosivos colocados en el Centro Judío de Buenos Aires este mismo año nos dice que no ha desaparecido y que sigue presente.

Un ejemplo clásico de terrorismo internacional es el apoyo que prestó el Ejército Rojo Japonés al terrorismo palestino en 1972 con la matanza del aeropuerto de Lod. Ante la dificultad de entrar en territorio israelí de los terroristas árabes, la acción se encomendó a los japoneses. Existen más ejemplos: el secuestro y asesinato de atletas israelíes en las Olimpiadas de Múnich, el secuestro de dirigentes de la O.P.E.P., la participación de "Carlos" en múltiples acciones terroristas, etc.

Los lazos internacionales terroristas podrían, según transcribe Grant Wardlaw en su libro "Terrorismo político", propiciar lo que llama "guerra sicaria". Dice así: "Podría suceder que en el futuro se aceptase el terrorismo como procedimiento legítimo de guerra, aunque ahora la rechacen como tal la mayoría de las instituciones militares convencionales." 
"Se podrían emplear terroristas para provocar incidentes internacionales, crear la alarma en el país adversario, obligando a desviar recursos valiosos para protegerse, destruir su moral y realizar formas concretas de sabotaje. Los gobiernos podrían emplear grupos terroristas existentes para atacar a sus adversarios, o bien crear sus propios terroristas. La inversión que requiere el terrorismo es pequeña, mucho menos ciertamente que lo que cuesta hacer una guerra convencional".

Dice el mismo autor que el terrorismo contemporáneo puede ejercer una influencia mayor que nunca y hay síntomas de que, en el futuro, algunos de los grupos que recurren al terrorismo no se impondrán las limitaciones que (cualesquiera que fueran las atrocidades cometidas) tenían antes.

Tom Clacy, en su novela "Pánico Nuclear", toma como eje de la acción la fabricación de un artefacto nuclear por parte de un grupo palestino y su activación en E.E.U.U.. Esta trama, entiendo que es futurista como lo fueron las de los libros de Julio Verne. El viaje a la Luna se ha conseguido y la "vuelta al mundo en 80 días" hoy se puede realizar en muchas menos horas.

Últimamente, estamos viendo que una de las consecuencias de desmembramiento de la U.R.S.S. es el tráfico ilegal de material radiactivo por falta de control sobre el mismo por los gobiernos de los nuevos estados. Ello altera a los gobiernos, ya que la hipótesis de trabajo de Tom Clacy no es difícil de cumplir. Técnicamente se puede construir con cierta facilidad un artefacto nuclear. Lo más importante es el material radiactivo adecuado. Si este material cae en manos de un grupo terrorista, éste podría chantajear a algún gobierno y probablemente sus peticiones serian atendidas.

Hemos visto, en lo que se ha expuesto, ejemplos de apoyo entre grupos terroristas, acciones en terceros países, comercio de posibles artefactos, posibles procedimientos de un Estado contra otro Estado, etc. Ello ha llevado a diversos autores a intentar hacer una clasificación de este tipo de terrorismo "ecuménico", partiendo de la base de que no existe un acuerdo general acerca de un significado.

Así, se podría hablar de:

- Terrorismo internacional, en el que la operación se dirige contra los intereses de un Estado distinto del elemento promotor de aquella, sea éste otro Estado o bien un grupo nacional sin Estado. En el primer caso, se trata realmente de una forma de acción indirecta entre Estados (Lo que Laqueur definía como Guerra Sicaria). En el segundo caso, cuando el elemento promotor es un grupo nacional sin Estado, su acción adquiere carácter internacional si se produce en el exterior del Estado adversario (Al Fatah, contra intereses judíos en terceros países)

- Terrorismo interno contra objetivos de otra nación cuyas acciones sobrepasan las acciones del propio Estado.

- Terrorismo transnacional aplicado a aquellos terroristas que operan internacionalmente con la finalidad de promover una revolución mundial. En cualquier caso, está comprobado el apoyo entre grupos terroristas para realizar operaciones determinadas o el apoyo en circunstancias difíciles.

\section{LA LUCHA CONTRA EL TERRORISMO}


Si la lucha contra el terrorismo (no la guerrilla), la enmarcamos dentro de la lucha armada, nos encontraremos ante una nueva forma de guerra, ya que el enfrentamiento armado es el que da carácter al conflicto. Este realmente no existe, ya que uno de los contendientes -el grupo terrorista- evita el enfrentamiento, sólo actúa cuando tiene la seguridad de que no va a recibir respuesta, se cubre con el anonimato y después de realizar una acción se sumerge en la masa urbana, siendo prácticamente irreconocible.

Por ello, combatir el fenómeno con fuerzas policiales manteniendo al ejército Riera de la contienda es la norma general adoptada en los países europeos. (La intervención del ejército inglés en Irlanda del Norte, habría que estudiarlo como algo singular. Mi opinión es que actúa más como fuerza de interposición entre dos grupos terroristas). También, como singular, podría estudiarse la actuación del S.A.S. en la liberación de rehenes en una embajada.

\subsection{EMPLEO DE EJÉRCITOS}

Admitir el hecho de que se trata de una guerra conduciría al empleo de las Fuerzas Armadas y a la aplicación de la legislación peculiar de ese Estado. El estado de guerra es sólo justificable cuando la Nación se encuentra en un situación realmente crítica. ¿Crea el terrorismo un situación tan crítica que aconseje el que se declare el estado de guerra? La respuesta a esta pregunta nos da la norma a seguir. En la Europa Occidental, ningún grupo terrorista ha creado una situación de crisis social. La indignación popular o la impotencia de las fuerzas policiales para eliminar a los grupos terroristas no pueden interpretarse como una situación de crisis. Para que ello fuera así un grupo armado tendría que ocupar un territorio sobre el que ejerciese dominio y desde él lanzar acciones contra el adversario. Este hecho no se ha dado nunca y no es previsible que en un futuro se pueda dar.

En documentos sobre el terrorismo (CESID), se opina que la acción de grupos terroristas en países industrializados con sistemas democráticos, que creen situaciones nacionales muy graves, se traduciría, probablemente, en un aumento creciente de responsabilidades directas o indirectas de las Fuerzas Armadas, sin que el poder político deje de mantener la dirección. Estiman, igualmente, que en el camino ante la normalidad democrática y el posible triunfo final de los fines terroristas, uno de los obstáculos fundamentales será un ejército puesto al día y preparado para cumplir una misión en este terreno.

De la oportunidad y dosificación de su intervención en cada una de las amenazas y de la capacidad de adaptación de la mentalidad militar al fenómeno dependerá su éxito operativo y disuasorio. En muchas naciones, ante el dilema Ejército-Policía, como instituciones para luchar contra el terrorismo, se han utilizado y utilizan instituciones que Gran Wardlaw denomina la "Tercera Fuerza", organizados en estructuras de carácter militar pero con funciones policiales: Carabinieri, italianos; Guardia Federal de Fronteras en Alemania; Guardia Civil, en España).

En el empleo de los ejércitos en la lucha antiterrorista encontramos dos posturas opuestas. Kitson, un autor inglés afirma que el ejército en el Remo Unido tiene la obligación de mantener la ley y el orden por tanto, combatir el terrorismo es una 
tarea que le incumbe. No obstante propugna una completa coordinación cívicomilitar y acepta la responsabilidad que tiene el gobierno de cribar las propuestas militares para asegurarse de que no dificultan los planes del gobierno a largo plazo. Este autor sostiene que el ejército está especialmente cualificado para combatir la subversión, para crear la red de espionaje vital para combatir a los terroristas y dirigir operaciones de guerra psicológica.

Wilkinson reconoce que el ejército esta especialmente dotado para llevar a cabo algunas acciones en la lucha antiterrorista como pueden ser los reconocimientos nocturnos o su mayor pericia en el uso y desactivación de bombas. Ello no es óbice para que acto seguido señale cuáles son las desventajas que puede tener el uso de soldados. Estas en resumen son las siguientes:

- Coste elevado

- Tensión indebida a la que somete la fuerza.

- Efectos corrosivos de las patrullas en la ciudad sobre la moral militar.

- Efectos corrosivos sobre la moral militar por la limitación de la respuesta que se puede dar a las provocaciones y acciones de los terroristas.

- Exacerbación de las divisiones sociales por el uso prolongado del ejército en funciones de seguridad.

- Los soldados son siempre extraños en la ciudad donde van a ejercer funciones de seguridad y pueden provocar en la población resentimiento y hostilidad.

- La hostilidad de la población puede convertirse en agresión cuando algún soldado, por infrecuente que ello sea, cometa algún error.

- Convierte en una guerra de gran escala movimientos que están en mucho menor escala.

- El dar una dimensión militar permanente en un área hace subir la violencia comunal a un nivel más estable y formal.

Cada una de estas afirmaciones merecería ser analizada detalladamente. Es probable que llegáramos a la conclusión que algunas de ellas puedan ser rechazadas o matizadas pero otras habría que admitirlas como suficientemente fundamentadas.

Si ponemos en una balanza la razones a favor y en contra del empleo de los ejércitos, tendremos que admitir que las favorables se fundamentan en esa fondón de seguridad genérica que es la razón de ser de los ejércitos, mientras que las desfavorables son de carácter pragmático y puntualizan previamente que esa función de seguridad queda perfectamente cubierta por la fuerzas policiales.

Los ejércitos contemporáneos están concebidos para oponerse a fuerzas que tengan una dimensión importante. Las fuerzas policiales cubren satisfactoriamente lo que podríamos denominar las amenazas que pueden provenir de acciones individuales o de grupos de escasa capacidad de acción siempre y cuando se las dote adecuadamente. Tanto los ejércitos como la policía son merzas que pertenecen a la nación y cada una de ellas tiene zonas de acción concretas. El empleo de una de ellas, o de las dos simultáneamente, debe de estar en fondón de la búsqueda de una mayor eficacia entendiendo esta como el permitir que la vida de los individuos que componen una sociedad pueda desarrollarse con normalidad. Esto nos hace 
afirmar que las organizaciones terroristas no poseen una fuerza lo suficientemente importante que justifique el empleo de los ejércitos. Esto no quiere decir que no puedan colaborar o prestar apoyo a la policía en acciones muy concretas.

\subsection{LAS FUERZAS POLICIALES}

Las fuerzas policiales convencionales no están preparadas para luchar contra el terrorismo. Los estados que se enfrentan a este fenómeno preparan grupos especiales para que puedan hacer frente al terrorismo. Sólo en los casos en el que las organizaciones no cuentan con una base de apoyo en la población es cuando pueden tener éxito tal como sucedió en Francia, Alemania o Italia. Cuando no es así, las acciones policiales son siempre de limitado alcance y por lo general no logran debilitar la estructura que mantiene la acción.

Las organizaciones terroristas, al igual que cualquier otra clan destina, tienen una estructura de mando colegiada que nunca se reúne en su totalidad. Sus miembros liberados, colaboradores o simpatizantes, sólo conocen la parte en la que prestan sus servicios. Son medidas de seguridad que no deben vulnerarse. Por esto la detención de cual quiera de sus miembros no pone en peligro la capacidad de acción.

La acciones de la policía lo único que consiguen es llenar las cárceles de presos que se convierten en uno de los principales focos de reivindicación y propaganda. Si nos detuviéramos a analizar el caso español, veríamos hasta qué punto la existencia de presos es importante para ETA. Esto nos ha hecho pensar más de una vez, que es probable que algunas detenciones hayan sido "facilitadas" desde la misma organización.

La gran limitación que tiene la policía es la que se deriva de la misma ley. Esta es una de las grandes paradojas de la lucha contra el terrorismo. Ningún movimiento terrorista extiende documento acreditativo de pertenencia, ni lleva uniforme o prenda alguna que lo identifique. Son ciudadanos normales, sumergidos en la sociedad, que hacen una vida normal y que aparecen sólo en momentos determinados. Las pruebas de pertenencia sólo se dan cuando se les demuestra la participación en algún acto terrorista que haya reivindicado la organización.

Para combatir a unos pocos terroristas se necesitan miles de policías. No se ha hecho una evaluación sobre el costo que supone a un Estado luchar contra el terrorismo. Si alguien se anima a hacerlo, la cifra será astronómica.

\subsection{LOS SERVICIOS DE INFORMACIÓN}

Se habla mucho, yo diría que demasiado, de los Servicios de Información del Estado y muy poco de estos mismos servicios de aquellas organizaciones, legales 0 ilegales, que tienen una guerra declarada al Estado.

Sin tener que hacer una exhaustiva investigación, ni de desvelar secretos de la organización etarra, por las acciones que llevan a cabo, es obvio que necesitan información, luego es fácil deducir que existirá un departamento que se dedique a la 
obtención de la misma. Los procedimientos para conseguir esta información son, como los de todos los servicios, múltiples y variados: desde la infiltración o captación de hombres suyos en las entidades bancarias para tener datos sobre los activos financieros de personas o empresas, el seguimiento y vigilancia de sus potenciales víctimas, las escuchas telefónicas y radio o el análisis de la información publicada en los medios de comunicación constituyen algunas de sus maneras de actuar. Si a esto añadimos otras acciones que les son propias tales como el chantaje, los daños materiales y tísicos o el asesinato si lo consideran conveniente, presentando estos hechos como la ejecución de sentencias de tribunales del pueblo, tendremos una idea de cuáles son sus formas de acción.

La propaganda etarra, muy hábil en el empleo de la terminología, encuadra estos agentes en los denominados "comandos de información". Se presentan como colaboradores de ETA, con escaso grado de vinculación a la organización y sin ninguna responsabilidad en las acciones cruentas que se puedan derivar de sus informaciones. Son, como se ha escrito, simpatizantes que colaboran y que en un futuro pueden adquirir un mayor grado de compromiso. La palabra "espía" no aparece nunca, y cuando son sorprendidos realizando sus actividades, muchas veces los jueces no consideran que hayan cometido ninguna falta o delito: anotar matriculas de coches en un papel, por ejemplo, no está penado en nuestros códigos.

ETA sabe que su principal enemigo son los Servicios de Información, sean estos el CESID, los de la Policía Nacional, los de la Guardia Civil o los de la Policía Autonómica. Como es lógico, impedir su labor será una línea de acción permanente y prioritaria. Como es obvio, para llevar a cabo esta misión tiene que contar con los medios adecuados. Lo ideal sería eliminarles. ETA sabe que no tiene capacidad para conseguirlo. La línea alternativa que le queda es desarticularlos con el fin de disminuir su capacidad de acción y restarles eficacia. Como es normal en su estrategia global, el arma que utilizarán es alimentar a la opinión pública para que la presión social sobre el Gobierno obligue a éste a tomar toda una serie de medidas que impida o dificulte la acción de los Servicios.

Si analizamos lo que ha sucedido en estos últimos tiempos descubriremos cuál es la estrategia que siguen para conseguir sus fines. En primer lugar, desacreditar ios servicios ante la opinión pública.

Para ello siguen tres líneas de acción:

1) Presentan a sus agentes como unos incompetentes.

2) Como personas carentes de cualquier principio moral.

3) Se dedican a labores informativas no propias del Servicio.

Para ello, necesitan descubrir alguna de las operaciones de los Servicios y contar con medios de difiisión a través de los cuales puedan dar a la opinión pública una versión de los hechos en la que se pongan de manifiesto la incompetencia, la falta de ética y la improcedencia de la labor que están realizando. En ningún momento tratarán de presentar el desenmascaramiento de esta operación como un logro de sus servicios de contrainteligencia. El diario "Egin" aceptará cualquier documento que se le facilite sin que presumiblemente realice una verificación en profundidad sobre su posible manipulación o autenticidad. La credibilidad de la fuente que les 
suministra la información es para el periódico una garantía suficiente. Por la propia naturaleza de los Servicios, saben que estos no entrarán a discutir ninguno de los supuestos documentos

que se les imputen.

El éxito de estas acciones depende, en gran medida, de la resonancia que tengan en los demás medios de comunicación. Para ello hay que presentar los hechos, no como una acción dirigida contra la organización terrorista, sino como una vulneración de los principios constitucionales. En la medida que personalidades de la vida política opinen sobre el suceso y que los supuestos vigilantes de la pureza del sistema democrático intervengan en la polémica, las probabilidades de éxito son mayores.

Si seguimos los últimos acontecimientos, comprobarán que lo primero que se solicita es la dimisión del Director general del Servicio, la reorganización del CESID y el control riguroso de las operaciones llevadas a cabo con el fin de crear un sistema muy rígido que disminuya la libertad de acción y lo haga ineficaz. Todo ello bajo el argumento supremo del respeto al Estado de Derecho.

En estas polémicas intervienen tres actores: los enemigos de los servicios, los utópicos y el Gobierno.

Los enemigos del servicio, además de la organización etarra, son todos aquellos que se sienten amenazados por los mismos. En una conferencia organizada por el Club Winterdiur y pronunciada por el general Calderón el pasado 24 de marzo en un hotel madrileño, a la hora de definir los riesgos que actualmente existen apuntaba los siguientes:

- La proliferación de armas de destrucción de masas

- El narcotráfico internacional

- El crimen organizado internacional con un sistema financiero cada vez más sofisticado.

- El terrorismo internacional

- Los sistemas de información de los que hay que preservar la confidencialidad, la integridad y la disponibilidad.

Es evidente que ningún Gobierno puede ser indiferente ante estas amenazas y que para combatirlas tome las medidas adecuadas. Los servicios de información son uno de los instrumentos que colaborarán en esta tarea. Sin necesidad de entrar en una análisis detallado de quiénes están detrás de estas amenazas, es fácil deducir que se trata de organizaciones poderosas, capaces de movilizar grandes recursos económicos y humanos. Es lógico pensar que todas ellas tratarán de neutralizar la acción de los Servicios y que colaborarán espontáneamente, de forma directa o indirecta, con cualquier iniciativa que propicie su neutralización. Es difícil tener un conocimiento exacto de las conexiones existentes entre este mundo de la delincuencia y la legalidad, la sutileza de los vínculos de conexión no es siempre fácil de detectar. Lo que pretendo poner de manifiesto es que los Servicios de Inteligencia tienen, en nuestros días, enemigos muy poderosos.

Los utópicos forman ese gran coro de gentes bien intencionadas que piensan que todos los males del hombre se derivan de una mala organización social. Los 
Servicios de Información que actúan en la sombra representan para ellos una seria amenaza ya que potencian y desarrollan Jo que denominan el juego sucio. Defensores a ultranza de la transparencia absoluta como única garantía del buen hacer, no aceptan el secretismo, ni la transgresión de cualquier principio que ellos consideren fundamental aunque sea en beneficio de la sociedad. Sin declararse enemigos de los Servicios, las medidas que

ellos proponen conducen de hecho a su total ineficacia. Muchos de estos se convierten en vigilantes del sistema democrático entendiendo este como un sistema filosófico y no como una manera de organizar el Estado. Es incuestionable que gozan de la simpatía de grandes sectores de población que los consideran la voz profunda de la conciencia social. Cuando se da conocimiento de una actuación de los servicios que pueda haber vulnerado alguno de sus principios, sus voces se elevarán de tono y nos recordarán, una vez más, cómo el hombre se ve amenazado por un sistema social creado para sostener unos mecanismos de poder carentes de cualquier norma ética y reclamarán un control férreo de sus actividades y el sometimiento de las mismas a un rigurosísimo control. Los argumentos que repetirán hasta la saciedad es el respeto al Estado Derecho y que en ningún caso el fin justifica los medios.

Por gobernantes entendemos tanto aquéllos que forman el ejecutivo del Estado o de cualquier Comunidad Autonómica u ocupan un puesto en cualquiera de las cámaras en donde está representada la soberanía popular. No es por tanto un bloque homogéneo.

Los Servicios de Información como órganos dependientes del poder ejecutivo de la Nación, pueden escapar al control de muchos de los que componen este heterogéneo grupo. Es más, para alguno de ellos puede constituir una seria amenaza si se utilizan para someterles a vigilancia y facilitar información sobre algunas de sus actividades que quieren que no sean conocidas por los grupos rivales. Esto lleva como consecuencia que reclamen de forma insistente un control riguroso sobre cuáles son sus actividades.

Para que esto sea posible tienen que propiciar una estructura que facilite ese control. Cualquier incidente que suceda será motivo para que esa pretensión aflore y que vuelva a repetirse el debate y se proponga una reorganización de los servicios con el fin, no de

buscar una mayor eficacia, sino de compartir el control de los mismos junto con el ejecutivo.

Esta somera descripción de los actores sociales que pueden verse afectados por los Servicios, nos explica de forma clara cómo cualquier denuncia que se haga contra los mismos, por débiles que sean las pruebas que se presenten, encenderá vivas polémicas y repercutirá de forma negativa sobre su labor. Los estrategas de la contrainteligencia etarra han hecho un análisis de la situación igual o parecido al que acabo de exponer. Las posturas de los diferentes grupos no van a cambiar, las motivaciones internas que los dirigen están sólidamente afianzadas y por mucho que se diga permanecerán.

Pienso que, fruto de esta tensión, los diferentes Ejecutivos han cometido algunos errores: el primero y más importante es lo que podríamos llamar la funcionarización del Servicio, lo que lleva implícito una enorme rigidez en materia de personal con 
todos los problemas que de ello se derivan; el segundo, entrar en una situación de reforma permanente lo que da a sus integrantes sensación de inestabilidad y el tercero, el no disponer de los recursos adecuados para abortar los protagonismos personales de los miembros disidentes, hecho que ha sucedido y que continuará sucediendo, y que convierten a estos personajes en la prueba fehaciente para fundamentar la desconfianza sobre las actividades que llevan a cabo.

\subsection{LOS POLÍTICOS}

A los gobernantes compete la dirección de la lucha antiterrorista. Son ellos los que tienen que determinar qué fuerzas se utilizan, la cantidad y la estrategia que se va a seguir. Por lo general, tratan de reducir el conflicto a un hecho puntual de escasa importancia que sólo se menciona cuando tiene lugar algún acto terrorista.

La estrategia que se diseña sigue los siguientes puntos:

1) Prevención de los actos terroristas. Para ello se diseña un sistema de protección pasiva de todas aquellas personas o lugares que pueden ser susceptibles de ser un objetivo terrorista. En lo que se refiere a las personas se adoptan dos sistemas: facilitar medios materiales (coches blindados) y personal (escoltas) para que sean objetivos difíciles de alcanzar, o proyectar sobre la posible víctima la responsabilidad de su defensa dándole una serie de instrucciones para su autoprotección.

Los lugares sensibles a la acción terrorista adoptan sistemas de protección que van desde patrullas de vigilancia, cámaras, prohibición de circular o aparcar en una determinada zona, etc. Todo lo anterior tiene un gran coste 0 lo que es mucho más grave, se emplean fuerzas para estos menesteres que tendrían que estar en otros lugares. Un ejemplo digno de análisis es lo sucedido con motivo de los atentados que han sufrido concejales del Partido Popular en Euskadi. A partir de la muerte del concejal Blanco, todos los ediles reclamaban un sistema de protección consistente básicamente en disponer de escoltas y vigilancia sobre su domicilio y bienes.

2) Detención de los terroristas. Es la parte activa del plan y ésta se encarga a la policía. Este punto ya se ha tratado con anterioridad.

3) Aislamiento de la organización. El aislamiento tiene tres campos de acción: en las zonas en las que tiene gran número de simpatizantes, a nivel nacional y a nivel internacional.

Las acciones que se realizan llevan dos direcciones: las dirigidas a la población y las que tienen por objetivo las fuerzas políticas.

Las dirigidas a la población muchas veces se limitan a la organización de manifestaciones con motivo de cualquier acto terrorista que haya producido alarma social. Las que van a dirigidas a las fuerzas políticas, se limitan sólo a aquellas fuerzas que no están en sus objetivos los mismos que reivindican los terroristas. En el caso de Euskadi, el llamado frente nacionalista formado por el PNV, EE y HB es una prueba de que todos los intentos de aproximación realizados durante 20 años han sido inútiles.

4) La negociación. Descartada la victoria militar, como ya hemos dicho, la negociación es la única alternativa de los movimientos terroristas para alcanzar sus objetivos, esto hace que tengan siempre preparada, lo que podríamos denominar, un orden del día para iniciar unas negociaciones. Los 
presentan como reivindicaciones irrenunciables. Los gobernantes niegan la posibilidad de cualquier negociación pero entran en contacto con lo que podríamos denominar, intermediarios válidos y grupos políticos afines. La "paz" alcanzada por los británicos con el IRA y la "tregua" en España con ETA, es fruto de esta estrategia. Una negociación con intermediarios siempre es frágil ya que en cualquier momento puede ser desautorizada por la cúpula de la organización que siempre guardará intacta una parte de su capacidad de acción. Las fuerzas políticas afines a la organización tienen que mantener aquellas reivindicaciones que son iguales a las del grupo terrorista y demostrar que se hacen progresos, de lo contrario la "paz" o "tregua" puede romperse. Este es el factor implícito, el que va a condicionar la acción de los gobernantes.

\subsection{LOS MEDIOS DE COMUNICACIÓN SOCIAL}

En las democracias, los medios de comunicación social se sienten utilizados por el terrorismo. Su actuación está sometida a una enorme contradicción: por un lado, la necesidad de informar a la población y por otro, la certeza de que estas informaciones producen alarma social y en consecuencia, contribuyen a los fines que pretenden alcanzar los terroristas que no son otros que presionar al poder constituido a través de la opinión pública. Esta contradicción se resuelve por lo general mediante lo que podríamos denominar una información adjetivada, es decir, empleando adjetivos peyorativos para los miembros de la organización: asesinos, delincuentes, sanguinarios, cobardes, fascistas etc. Esto justifica grandes titulares, imágenes escalofriantes y un sinfín de declaraciones que incidan en las mismas calificaciones.

Si tenemos en cuenta la hipótesis, cada vez más admitida, de que los medios de comunicación dan información y que la opinión la ponen los lectores, nos daremos cuenta de lo equivocado que es este planteamiento. Es obvio que los que son contrarios a las acciones terroristas, con estas descalificaciones se verán gratificados pero los que son favorables las rechazarán y la gratificación la encontrarán en el resulta

do de la acción. El resultado de esta política informativa no puede ser otro que profundizar en la división existente en el seno de la sociedad.

Otro factor a tener en cuenta es el denominado efecto de jerarquización de la actualidad que realiza la prensa. La importancia de un suceso viene determinada en función del tratamiento informativo que dé la prensa al mismo. La noticia con la que se inicia un programa informativo en radio o televisión o la que sirve para abrir la primera página de un periódico es lo más importante que ha sucedido ese día. Las rutinas que dominan el quehacer periodístico establecen reglas que obligan a determinados tratamientos. Así, relegar a un segundo plano informativo un acto terrorista, puede ser interpretado como una desconsideración hacia las víctimas del mismo o una actitud poco firme frente al terrorismo.

Estas contradicciones marcan el quehacer informativo, sin que hasta el momento se haya encontrado una fórmula aceptado por todos, capaz de resolver el dilema entre lo favorable y desfavorable para los terroristas. La dirección que señala el 
conocimiento científico es que tratasen de limitar los efectos de alarma social que hoy se produce. Para que esto fuera posible, sería necesario llegar a un consenso entre los medios de comunicación respecto al tratamiento que hay que dar a este tipo de información sin que ello tenga que afectar a los contenidos. En un clima de libertad informativa para las empresas propietarias de los medios en donde cada vez son más importantes las audiencias, es poco previsible que este acuerdo se alcance. De cualquier manera el intento valdría la pena.

\section{CONCLUSIÓN}

En estos momentos parece que estamos asistiendo a un lento retroceso de las acciones terroristas en el mundo occidental debido principalmente a una reconducción de los nacionalismos hacia posiciones menos radicales. La posibilidad de un nuevo diseño del mapa político en ese nuevo Estado, que será a medio plazo, la Unión Europea ofrece posibilidades que hasta este momento no habían sido contempladas. La eliminación de las fronteras, la libre circulación de las personas, la moneda única, una política exterior común y unas nuevas Fuerzas Armadas que se perfilan como consecuencia de la necesidad de emprender acciones exteriores, conducen irremediablemente a ese Estado Europeo al que nos referíamos antes. Es obvio que esto conduce a una debilitación de los estados actualmente existentes y aun mayor protagonismo de los llamados estados federales, autonomías o regiones. Este puede ser el motivo por el que se haya rediseñado una nueva estrategia consistente en buscar cada vez cuotas de autogobierno más elevadas, con la esperanza de con el tiempo, poco a poco, los actuales estados se desvanezcan.

\section{BIBLIOGRAFÍA:}

- ACTAS TUPAMARAS. Una experiencia de la guerrilla urbana a la Revolución. Madrid, 1982.

- BAADER-MEINHOF. EI moderno estado capitalista y la estrategia de la lucha armada, Icaria. Barcelona, 1981.

- BECKER, Jullián. Los hijos de Hitler. Historia de la banda terrorista BaaderMeinhof. Anaya, Barcelona, 1979.

- CARO BAROJA, Julio. Terror y terrorismo. Plaza \& Janes, Barcelona, 1989.

- CONSEJO DE EUROPA. Informe del terrorismo en Europa. Ministerio del Interior, Madrid, 1979.

- CHE GUEVARA, Ernesto. Diario de Bolivia. Che. Equipo Editorial, S.A., San Sebastián, 1968.

- CHE GUEVARA, Ernesto. La guerra de guerrillas. Ediciones Júcar, Madrid, 1977.

- $\quad$ DEBRAY, Régis. La guerrilla del "Che". Siglo XXI, México, 1975.

- DEBRAY, Régis. Révolution dans la Révolution?. F. Maspero, París, 1967.

- DESANTES GUANTER, José María y otros. Prensa, paz, violencia y terrorismo. La crisis de credibilidad de los informadores. EUNSA, Pamplona, 1987.

- $\quad$ ETA. ETA en sus documentos (10 tomos), Hórdago, San Sebastián. 1980.

- GARMENDIA, José María. Historia de ETA. 2 tomos. Luis Aramburu, San Sebastián, 1979.

- LAQUEUR, Walter. Terrorismo. Espasa-Calpe, Madrid, 1980. 
- $\quad$ MAO TSE TUNG. Guerra de guerrillas. Huemel, Buenos Aires. 1968.

- MARIGHELLA, Carlos. Teoría v acción revolucionaria. Diógenes, México, 1970.

- MARIGHELLA, Carlos. La guerra revolucionaría. Diógenes, México, 1971.

- MOSS, Robert. La guerrilla urbana. Editora Nacional, Madrid, 1973.

- MEINHOF, Ulrike. Carta de una presa y últimos escritos. Icaria, Barcelona, 1976.

- MERCADER, Antonio y DE VERA, Jorge. Los Tupamaros: Estrategia y acción. Anagrama, Barcelona, 1970.

- PESTAÑA, Ángel. Terrorismo en Barcelona. Planeta, Barcelona, 1979.

- RODRIGO ALSINA, Miguel. Los medios de comunicación ante el terrorismo. Icaria, Barcelona, 1991.

- WILKINSON, Paúl. Terrorismo político. Feldmar, Madrid, 1976.

- WARDLAW, Grant. Terrorismo político. Ediciones Ejército, Madrid. 